\title{
Study on Transformation of Trade Union Function based on Grassroots Governance Modernization
}

\author{
Qiyuan $\mathrm{Hou}^{1}$ \\ ${ }^{1}$ East China University of Political Science and Law, Shanghai, 200016 \\ hunter2011@foxmail.com
}

Keywords: Modern Governance; Grassroots Trade Unions; Functional Transformation

\begin{abstract}
The primary trade union organization is the base of trade country's union, and it links the people most closely, which directly face the complex labor relations. Under the influence of the traditional system, grass-roots trade unions is generally treated as a subsidiary of the existence of the party and government departments, functions play impeded. After 30 years of reform and opening, with the economic development, the number of non-public enterprises has gradually increased, but the rate of the grass-roots trade unions to safeguard the legitimate rights and interests of workers, as well as other aspects of social recognition weakening trend began to emerge. These are slow-building and grass-roots trade union organization positioning error, untimely reform is closely linked. The development of modern governance grassroots trade unions put forward new requirements. In order to meet the development needs of modern governance, grassroots trade unions should play a role and functioning transformation of grass-roots trade union is imminent.
\end{abstract}

\section{Introduction}

Eighteen Third Plenary Session of the first to reveal the intrinsic link between modernization and state governance, suggesting that China's development has once again entered a new stage. With the reform and opening up 30 years, China's economic system and industrial structure adjustment through a series of reforms, gradually become optimized, but also led to a change in distribution pattern, bringing differentiation of social interests and some conflicts of interest issues, governance modernization proposed to address these issues provide a grass-roots trade union direction as the closest ties with the masses of grassroots organizations should play to their functions, the role of the state to serve the belt between enterprises and workers, its functions should be transformed to meet the demands of the times, to promote the modernization of national governance.

\section{Development of Local Union Under Modern Vision of Governance}

Before 1978, China was a planned economy, the nature of labor relations is the relationship between the state and the workers, the state provides for all aspects of the arrangements and protection of workers at this time, the consistency is too much emphasis on social benefits, labor relations and labor adjustment of interests and ideological issues are socialization, thereby ignoring and obscures the differences between different interest groups, functions grassroots trade unions have also been diluted, it turns into a party committee offices and affiliated departments grassroots administration in the New development of trade unions put forward new requirements, but grass-roots trade union did not change its status, there are many problems in practical work.

Contradictory, grass-roots trade unions in an awkward position, when the interests of both the conflict, the role of trade unions of workers is often being replaced by tool role of the state.

Grass-roots trade union organizations of trade unions is to contact the masses in the most closely organized, should safeguard the legitimate rights and interests of workers in a prominent position on the establishment of a socialist market economy, the contradiction between the interests of government enterprises and workers among the increasingly complex and functions union rights has not kept pace modernization of union governance as to safeguard the legitimate organization of workers, but can not play its due role in most trade union cadres appointed by the company, in the face of a conflict of interest, in order to keep their own interests, have to toward the business or the 
government side, resulting in the interests of workers are not neglected guided grassroots unions, the masses of workers to maintain their rights consciousness fade over time, it is not difficult to find a form of organization of the phenomenon, slack, and some may even cause no necessary labor disputes, serious unintended consequences is not conducive to personal development last employees, is not conducive to the economic development of enterprises, at the same time pose a threat to social stability returned.

In recent years, a number of countries, while the introduction of laws and regulations on trade unions, but with the progress of reform, these rules do not keep up with the pace of reform, led to some problems in the actual operation, the workers or union no precise legal can rely on, for example, trade union law constraints for related behavior is not strong, many of the provisions have not been implemented expressly provided, or encountered many obstacles in the implementation lead to the closest relationship with the employees union law can not fully play its role For example, Article 23 of the Trade Unions Act to production safety responsibility and authority for the regulations, but for violation of this provision which should bear legal responsibility and no precise instructions and regulations and then, for example, Article 49 of the Trade Union Law violation of rights, the right to ask the relevant department, or sue regulations mentioned in the relevant sector to the people's court, but specifically what authorities have not clearly defined, workers encountered a problem I do not know where to representations Moreover, for infringement acts of infringement and to what extent to the courts, there is no clear explanation of these terms is not clear not clear, and ultimately leads to lower primary trade union legal authority.

\section{Grass-Roots trade Union Functions Transformation: from The Office to Assist Leading Activist}

From a functional point of view of grassroots trade unions, mainly to safeguard the legitimate rights and interests and democratic rights of the masses of workers, mobilize and organize the workers to actively participate in the reform and construction, to participate in national and social affairs, to participate in the democratic management of enterprises, institutions and bodies, and constantly improve the ideological education of workers moral qualities and scientific and cultural qualities of the planned economy period, countries in the development of arrangements for the employment of workers labor wages and labor policies have very clearly defined, the grass-roots trade union primarily as government offices and government departments assisted in this period exists, is State care for workers is more comprehensive, and therefore labor disputes, workers' rights issues is relatively weak socialist transition stage, in the national perspective of modernization of governance, the state no longer apply to the direct management of enterprises and institutions of a unified, non- increasing the number of public enterprises, labor relations increasingly complex It is understood that the existing non-public enterprises, wages and benefits substantially from the enterprise to be, but many companies do not follow state regulations and the level of prices, timely adjustment wages and in some migrant workers and temporary workers are more companies, there is also the case the company does not sign labor contracts with employees forced workers to work overtime wage arrears phenomenon also occurs when questions such serious violations of the legitimate rights and interests of workers, as grass-roots trade unions auxiliary departments, its functions continue to be weakened not only that, to be bound by our traditional ideas and institutions, trade unions' own construction can not adapt to the changing requirements of the times, seriously restricting the power of their own means and methods of work of grass-roots trade union, even if he wanted seek to change, there is the heart and weak.

Eighth session of the Third Plenary clearly put forward the theory of modern governance, reform of grassroots trade unions to provide a strong direction now, China's main government as the main body, using relatively passive management style, a certain degree of social stability threat , therefore, can not adapt to social development and sustainable development strategies, and a significant number of resource distribution rights and administrative examination and approval authority is still firmly in government hands, leading enterprises and institutions of local government and civil society organizations no separate space to play, limit their development is not 
to say, of economic and social development also had a certain impediment Therefore, to promote the modernization of national governance is to meet the demands of the times, both suited to the practice of reform requires institutional mechanisms, and constantly build new institutions and institutional mechanisms to promote the work of the party and state clearly institutionalized standardized procedures inherent requirement of modern governance, the progressive realization of the transformation of the functions of the grass-roots trade unions than ever before, at this stage of complex labor relations, labor conflicts gradually increased, grass-roots trade unions face The biggest problem is how workers' rights are effectively maintained, both to meet the requirements of party and government departments, safeguard the rights and interests of the masses of workers, while enhancing the vitality of the grass-roots trade union organizations to change their status as government aid departments, so its functions effectively transition to address the most prominent stage the core issue and therefore, in order to improve the status of grassroots trade unions, to play its due role, must be functional transformation, from the government's aid department, in order to safeguard workers' interests to develop into a the core of the dominant sectors.

Grass-roots trade unions as a subsidiary of government departments exist, in large part by the government and business administration control and constraints on the operation mechanism of cadre selection and processing financial balance of payments problems are biased in favor of government departments, leading to serious administrative tendency advance grass-roots trade union administrative reform not only regulate the operation of grass-roots trade unions' own, and its development is related to all aspects of society, all sectors with the deepening of reform and opening up, distribution patterns and economic interests of our society has gradually become diversified form and complex, these changes are the work of grass-roots trade unions made more explicit requirements in this new situation, the social status of grassroots trade unions increasingly heavy administrative reform tendency of grassroots trade unions, not only can make labor conflicts to be resolved, but also to promote the healthy development of enterprises and institutions, while governance and modernization of the country's current requirements and prospects of development coordination.

First of all, the grass-roots trade union chairman is mainly connected to the higher Party committees or appointed by the union organization, which is one of the important causes of the union president union administrative tendency unions direct election is the direction of reform, democratization and trade unions to adapt the requirements of the masses. It is also an important part of grassroots democracy but for the moment, in the direct election of the President of the primary trade union of the system have not gone smoothly for example, in Shanghai as an example, Shanghai to carry out the direct election of the President of the grassroots trade union work has been for years a pilot time but at home, the grass-roots trade unions, union president only directly elected position, only accounted for a grass-roots trade union organizations, but at the same time, there have been different from the previous new trade union organizations in a number of non-public enterprises, which by union president these new unions organize workers by way of democratic elections to labor conflicts arising from a confrontation toward negotiation, with the legal means to express and safeguard the rights and interests of workers, and also played a positive role in maintaining social stability.

Secondly, the grass-roots trade union funds management also contributed to the tendency of administrative sources of trade union funds, one of the provisions of the Trade Union Law Article 42 of the reasons there are two: First, union membership dues; the second is the establishment of trade union organizations in accordance with corporate bodies and institutions all monthly total wages paid twenty percent of funds allocated to the trade union; third income enterprises paid union belongs; Fourth people's Government subsidies present case, however, the grass-roots trade union funds mainly from in government subsidies, and therefore most of the grass-roots trade union organizing activities must rely on government forces, constrained by the government, leading to more serious administrative tendency now, should be strictly in accordance with the requirements of the Trade Unions Act, strictly regulate the funding of grassroots trade unions, to get rid of government control, while allowing the use of transparent funding, increase a sense of the masses of 
workers to the grass-roots trade union organizations trust.

Finally, grass-roots trade unions traditional operating mechanism leading to an important reason for the Chief of the traditional top-down union is to convey information, which led to rely on the superior grass-roots trade union work instructions, and did not really understand the grassroots needs of the masses of workers, the maintenance function natural lack of effective governance to play in the national modernization background, change the traditional party and government departments led the way, using a bottom-up operational mechanisms to the masses of workers most vital interests, will play in the deliberative democracy functions solve problems among workers rights, the tendency of the executive to change the operating mode to achieve the functions of the grass-roots trade union transformation.

From the perspective of self-construction, firstly should broaden the interests of the masses of workers express way, makes workers where there is union, union workers have difficulties to know to look for, so to promote the universality of the construction of grass-roots trade unions for some companies do not establish trade unions circumstances, should vigorously promote in-depth business education, promoting the formation of the Trade Union of workers turnover rate for temporary dispatch workers are not organized into trade union in the past, and should broaden the type of grass-roots trade unions, the different types of businesses gather together widely accepted various types of workers should also be the formation of a grass-roots trade union professionally trained cadres, effective performance of the functions of trade unions regularly organize public education activities to help employees raise awareness of rights and rights capacity in the workers' rights violations when you know what kind of effective legal means to safeguard their own interests.

\section{Conclusion}

In short, only the laws and regulations formulated by superiors effectively convey to the masses of workers around, can it truly realize the function transformation of grassroots trade unions. We have to the grassroots level, to actively promote and maintain good about workers' rights laws and regulations, and vigorously carry forward the spirit of the rule of law, enhance rights awareness in the masses of workers, such as the ability to improve the rights, grassroots trade unions can organize workers in the enterprises, workshops and other grassroots units to carry out legal advocacy, legal knowledge for the greater number of temporary and migrant workers now, we can network Books Street side billboards and other new ways to strengthen the rights of publicity of laws and regulations.

\section{References}

[1] Wu-Jian Q. Chinese Trade Unions of Transition Period-To Participate in National Governance Angle. Beijing: Guangming Daily Press, 2012.

[2] Wang Hong. New Development of Trade Union Reform and Grassroots Democracy in China -Non-Public -Enterprises Union Elections Case Analysis. South China Normal University: Social Sciences, 2004 (5).

[3] Luo Ping. Safeguarding Workers' Rights and Interests of The Grass-Roots Problems and Countermeasures. Chongqing: Southwest University, 2013.

[4] Liu Yong. The Basic Idea And Content of the Grass-Roots Trade Union Reform Temptation. Shaanxi Institute of Public Administration, 2014 (11).

[5] Liu-Dan N. On The Grass-Roots Trade Union Building and State-Owned Enterprise Reform In Transition. Economic Management Studies, 2014 (20). 